\title{
THE DEGLACIATION OF SIERRA NEVADA (SPAIN), SYNTHESIS OF THE KNOWLEDGE AND NEW CONTRIBUTIONS
}

\author{
A. GÓMEZ-ORTIZ ${ }^{*}$, M. OLIVA ${ }^{2}$, D. PALACIOS ${ }^{3}$, F. SALVADOR-FRANCH ${ }^{1}$, \\ L. VÁZQUEZ-SELEM ${ }^{4}$, M. SALVÀ-CATARINEU' ${ }^{1}$, N. DE ANDRÉS ${ }^{3}$
}

\begin{abstract}
${ }^{1}$ Departamento de Geografia Física y Análisis Geográfico Regional. Universidad de Barcelona, Barcelona, Spain.

${ }^{2}$ Departamento de Geografia. Universidade de Lisboa, Portugal. ${ }^{3}$ Departamento de Análisis Geográfico Regional y Geografía Física. Universidad Complutense de Madrid, Spain.

${ }^{4}$ Instituto de Geografía. Universidad Nacional Autónoma de México, México.
\end{abstract}

\begin{abstract}
The large number of studies of Sierra Nevada's environmental history since the Last Pleistocene glacial period makes it one of the most intensively analysed massifs in the Iberian Peninsula. The early geomorphological descriptions have been complemented in recent decades with absolute dating techniques that have allocated in time the sequence of environmental events occurred in Sierra Nevada during the last millennia. The maximum expansion of the glaciers during the Last Glaciation took place around 30-32 ka, with a subsequent re-advance by 19-20 ka. The process of deglaciation was very fast, and around 14-15 $\mathrm{ka}$ the ice had almost completely retreated from the massif. Since then, with greater or less intensity and extent, periglacial processes have driven the environmental change in the massif. The coldest and wettest phases during the Holocene have favoured the development of small glaciers in the highest northern cirques. The last of these phases was the Little Ice Age, where abundant historical sources and sedimentary records exist. During the midXX century the last glaciers melted, resulting in the complete deglaciation of the massif.
\end{abstract}

\section{La deglaciación de Sierra Nevada (España), síntesis del conocimiento y nue- vas contribuciones}

RESUMEN. Sierra Nevada es uno de los macizos ibéricos con mayor información de su último periodo glaciar pleistoceno. El análisis geomorfológico de campo se ha ido completando durante las últimas décadas con técnicas de datación absolutas que han permitido localizar en el tiempo los acontecimientos ambientales acontecidos en Sierra Nevada durante los últimos milenios. La máxima expansión de los hielos durante la Última Glaciación tuvo lugar en torno a 30-32 ka, con un reavance posterior en torno a 19-20 ka. La deglacia- 
ción, entonces, fue rápida y en torno a 14-15 ka el macizo estaba ya prácticamente deglaciado. Desde entonces, con mayor o menor intensidad y extensión, los procesos periglaciares controlan los cambios ambientales en el macizo. En la actualidad éstos fijan su límite inferior en torno a los $2500 \mathrm{~m}$. Durante el Holoceno las fases más frías y húmedas han conllevado la aparición de pequeños focos glaciares en los circos septentrionales de mayor altura. De ellas, la Pequeña Edad de Hielo ha sido la última y de la que mayor información se dispone, ya sea a través de fuentes históricas como de registros sedimentológicos. A mediados del siglo XX desaparecen los últimos vestigios glaciares, conllevando la deglaciación completa de Sierra Nevada.

Key words: Sierra Nevada, Quaternary, glacial processes, periglacial processes, absolute dates, historical documents.

Palabras clave: Sierra Nevada, Cuaternario, glaciarismo, periglaciarismo, dataciones absolutas, documentos de época.

Received 20 March 2015

Accepted 24 April 2015

*Corresponding author: Departamento de Geografia Física y Análisis Geográfico Regional. Universidad de Barcelona, Barcelona, Spain. E-Mail: gomez@ub.edu

\section{Introduction}

The deglaciation of the mountains in the European alpine belt is a large-scale process that has taken place at different time periods. Depending on the latitude, altitude and climatic conditions prevailing in the different massifs, this process has already been completed in the Iberian Peninsula or is still currently underway. This is the case of the Pyrenees, where small glaciers in disequilibrium still exist in some cirques, being the legacy of colder and wetter periods in historical times (González Trueba et al., 2008).

Most Iberian mountains with altitudes over $2000 \mathrm{~m}$ hosted glaciers during the Pleistocene cold stages (Domínguez-Villar et al., 2013). The intensity and extent of the Last Glaciation erased the traces of earlier glaciations, so that little geomorphological and sedimentological evidence remains of these, as in e.g. Sierra Nevada (GómezOrtiz and Pérez González, 2001). In contrast, the abundant landforms and deposits of glacial and periglacial origin from the last Pleistocene glaciation facilitate a better understanding of both the time scale and of the environmental conditions of the respective morphogenic domains.

Advances in dating techniques in recent years has made it possible to define a timeline for the maximum advance of the glaciers and their gradual retreat. Nevertheless, the wide spectrum of climatic conditions in the Iberian Peninsula-conditioned by its complex orography and altitude, orientation, oceanic and/or continental influence- has determined notable divergences in the age of the maximum ice extent in the different 
mountain systems, as occurs in the NW quadrant of the Iberian Peninsula in contrast with other glaciated massifs (Delmas et al., 2008, 2011; García-Ruiz et al., 2010; Palacios et al., 2011, 2012, 2014; Serrano et al. 2013).

The main aims of this article are:

- $\quad$ to synthesize the chronology of deglaciation phases in Sierra Nevada since the last Pleistocene glacial period and their morphological repercussions;

- $\quad$ to examine the environmental sequence in the natural systems of the Sierra Nevada summit areas during the last glacial period; highlight the glacial behaviour in the Little Ice Age (LIA) in Sierra Nevada, and

- $\quad$ to integrate the environmental dynamics in Sierra Nevada into the evolution observed in other mountains in the Iberian Peninsula and southern continental Europe.

\section{Study area}

Sierra Nevada, in the SE Iberian Peninsula, forms part of the axis of the Baetic System and is its highest area, with ridgelines exceeding 3300 m (Mulhacén, 3478 m; Veleta, 3398 m; Alcazaba, 3371 m) (Fig. 1). Sierra Nevada is a robust alpine massif, armoured in summit areas by series of metamorphic rocks in a Paleozoic substratum, with interspersed emergent micaschist series (Díaz de Federico et al., 1980). The morphostructure of Sierra Nevada is made up of different mantles, which include important faults and fractures that have conditioned the river network layout (Sanz de Galdeano et al., 1999), and of the remnants of summit erosion surfaces. The glaciation remained confined within the summit area, where glacial and periglacial landforms are widespread.
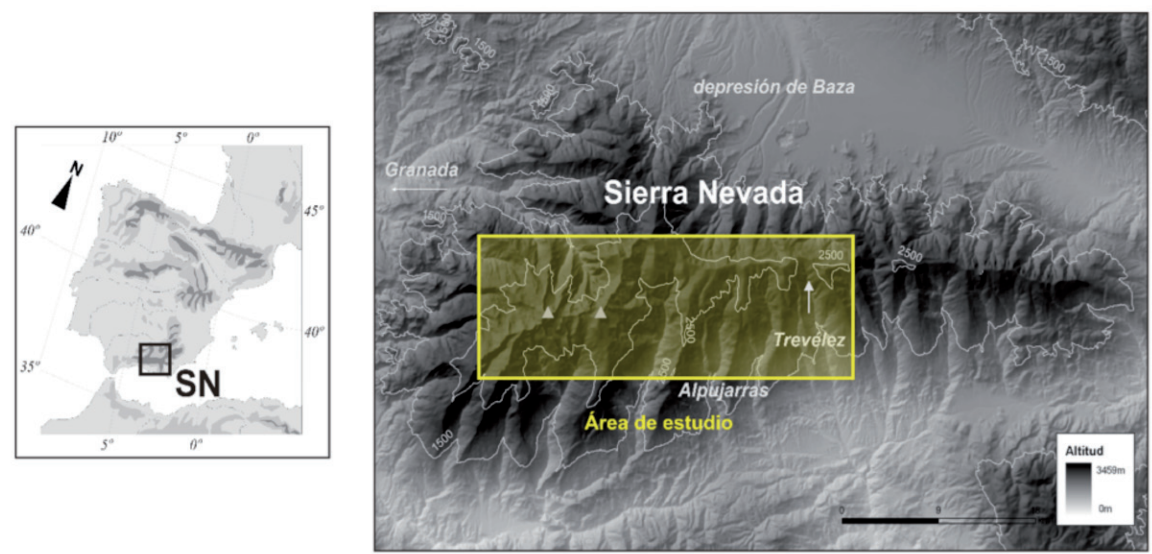

Figure 1. Location of Sierra Nevada within the Iberian Peninsula and study areas in the massif. 
The current climatic regime in Sierra Nevada corresponds to a semi-arid cold mountain climate with mean annual temperatures around $0^{\circ} \mathrm{C}$ on the summit areas at the highest elevations (Salvador-Franch et al., 2011) and $4.4^{\circ} \mathrm{C}$ at $2500 \mathrm{~m}$. The estimated annual precipitation at these levels is around $710 \mathrm{~mm}$ (Oliva, 2009). Snow cover starts in November above $2400 \mathrm{~m}$ and lasts until May-June, when snow patches only remain at elevations above $2900 \mathrm{~m}$. In snowy years they can persist the whole summer in nivation and glacial cirques, as it occurred in 2010, 2011 and 2013. These climatic conditions suggest that periglacial processes characterize the geomorphic dynamics in the highest lands in Sierra Nevada. Thus, in general terms, the area currently affected today by periglacial activity coincides with the predominantly glaciated surface during the Last Glaciation (Gómez-Ortiz and Salvador-Franch, 1992; Oliva et al., 2014). The current characteristic landscape of these mountain areas is predominantly bare ground or sparse vegetation as open cover, except in topographical depressions well supplied by late snowmelt waters, where grasslands with multiple endemisms are distributed (Molero Mesa and Pérez Raya, 1987). These endemisms are a consequence of the role played by Sierra Nevada as an ecological refuge during the Quaternary cold stages and the subsequent adaptation of the plant species to the prevailing climatic conditions (Blanco-Pastor et al., 2013).

The glaciers in Sierra Nevada, the southernmost glaciers in Europe, remained confined within the high valleys and valley heads, generally above $2500 \mathrm{~m}$, without reaching the low lands surrounding the massif (Fig. 2). Nevertheless, in some cases, such as the alpine-type glaciers in ravines with steep slopes, the ice masses reached altitudes below $2000 \mathrm{~m}$. The glaciated area must have covered around $320 \mathrm{~km}^{2}$ including the north and the south slopes, from Puerto de Trevélez (2799 m), in the east, to Cerro del Caballo (3011 m), in the west. This area, which coincides with the western fringe of the Sierra, includes the main valleys and their respective headwalls and during this stage was the home of important glacial systems including Trevélez, Siete Lagunas, Poqueira (Cornavaca, Lagunillos, Peñón Colorado, Veleta, Río Seco, Naute), Lanjarón, Dílar, Monachil and Genil (Hoya de la Mora, San Juan, Guarnón, Valdeinfierno, Valdecasillas, Vadillo).

The existence of glaciation in Sierra Nevada was first referred to by Boissier (1845), who mentioned the active cirque glacier enclosed in Corral del Veleta, at the head of the Barranco del Guarnón. References to Quaternary glaciations came soon after from Schimper (1849). From then on, especially after the observations made by Macpherson (1875) on the origin of the lakes in the Sierra, our understanding and explanation of glaciological, morphological and environmental events has gradually continued to evolve up to the present (Obermaier, 1916; Dresch, 1937; García Sainz 1947; Paschinger 1957; Messerli 1965), with the research also becoming gradually more precise and with greater scientific validity (Gómez-Ortiz, 1987, 2002). In this context, it is particularly worth noting the remarkable range of research conducted since the 1980s, with detailed analyses of the glaciated valleys and mapping of the glacial and periglacial morphology of the Sierra Nevada peaks (Gómez-Ortiz, 2002). This enabled a first approach to a precise timeline of glacial records (moraine deposits and abrasion surfaces in valleys

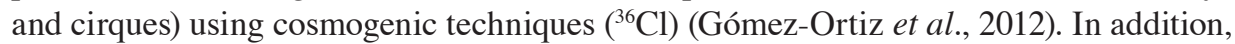
Holocene paleoenvironmental evolution was also approached through sedimentological 
analyses (lakes and solifluction lobes) and ${ }^{14} \mathrm{C}$ radiocarbon dating (Oliva, 2009; Oliva et al., 2011, 2014). In recent years, with the support of historical documentation and morphological records, the recent evolution of the historical glaciation of the Sierra linked to the LIA has also been confirmed and its spatial extension defined (GómezOrtiz et al., 2009).

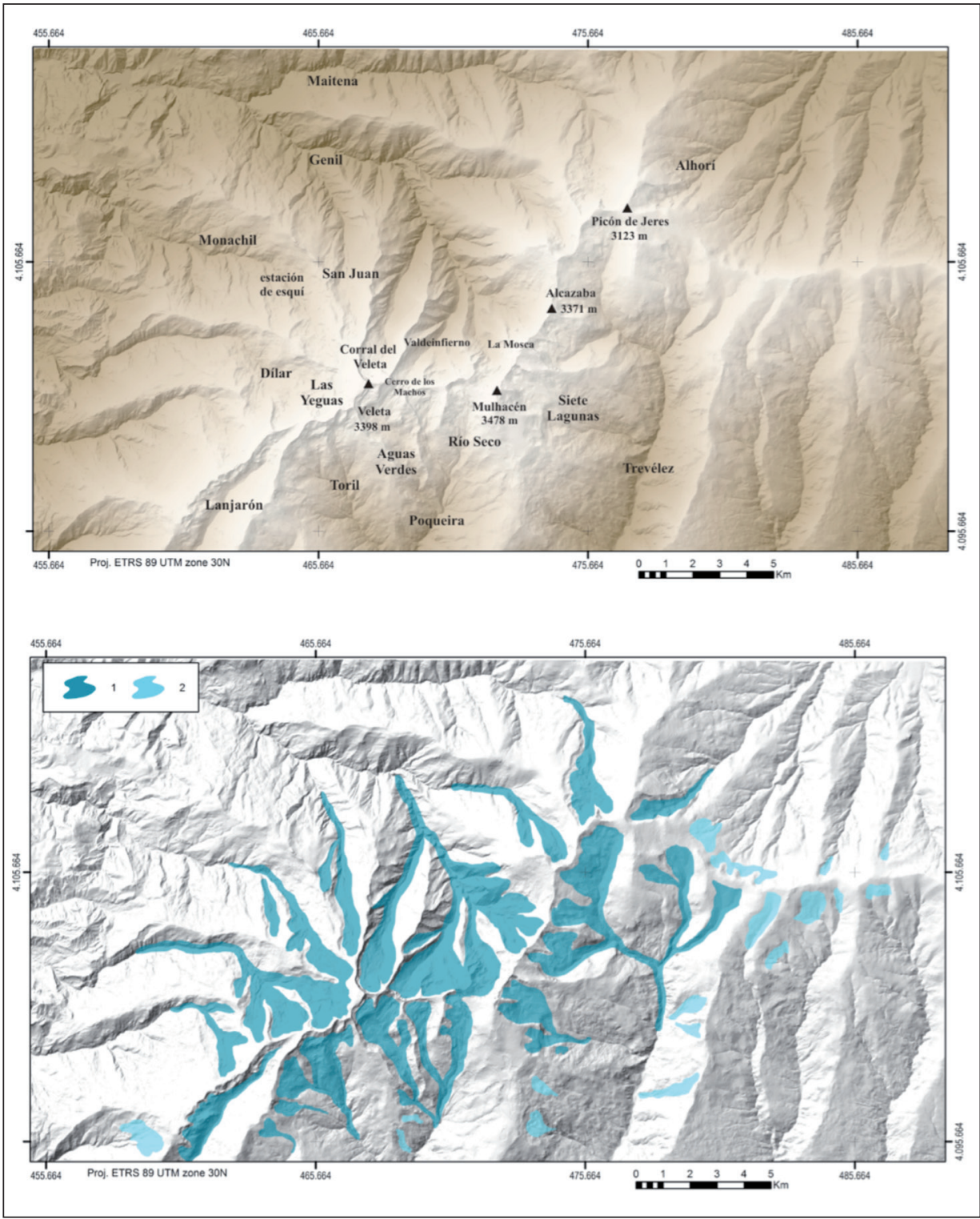

Figure 2. Maximum extension of the glaciers in Sierra Nevada during the Last Glaciation (figure below), and location of the sites mentioned in the text (figure above). 


\section{Materials and methods}

This paper, which is presented as a synthesis and includes new data contributions, takes into consideration all the recent research carried out to date relating to the Quaternary glacial evolution of Sierra Nevada, and in particular to its deglaciation process. Because of its relevance, the highest summit sector has been considered, in particular the Poqueira (side valleys of Mulhacén, Río Seco and Veleta), Dílar and Monachil valleys, as the best representation of the glaciated area in this massif. Abundant geomorphological information on these valleys is available (Gómez-Ortiz, 2002) as well as an absolute chronology of their glacial evolution. Of particular interest here is the updated research by Oliva et al. (2014) which compiles the results obtained by absolute dating techniques used up to the present in Sierra Nevada as a whole, including: ${ }^{14} \mathrm{C}$ dating $(41$ samples conventional and AMS), cosmogenic dating of exposed glacial surfaces (13 samples), ${ }^{210} \mathrm{~Pb}$ dating (3 samples) and ${ }^{137} \mathrm{Cs}$ dating (1 sample). With reference to events in the historical era, above all to the cirque glaciers which developed in the LIA and their evolution over time, information obtained from documentary sources during the Arab era to the mid- $20^{\text {th }}$ century has also been analysed and evaluated (Gómez-Ortiz et al., 2006, 2009), as well as results obtained from the current disintegration of the remnants of this historical glacial ice (Gómez-Ortiz et al., 2014).

\section{Results}

The most important studies of the glaciation in Sierra Nevada suggest the existence of different glacial periods during the Pleistocene (e.g. García Sainz, 1943; Hempel, 1960; Messerli, 1965; Lhenaff, 1977), although the best documented events in different time periods based on recent absolute dating start with the Last Glaciation (GómezOrtiz et al., 2012). Therefore, when discussing the history of the different glacial systems affecting the Sierra Nevada during the Quaternary, we differentiate between the glacial events occurring before and those that took place during the Last Glaciation.

\subsection{Glacial stages previous to the Last Glaciation}

Ever since the studies by Obermaier (1916) the existence of pre-Würm glaciations (using alpine terminology) in Sierra Nevada has been suggested, as occurred in other Iberian massifs, particularly in the Pyrenees (e.g. Solé Sabarís, 1951). In the case of Sierra Nevada these interpretations have always been deduced from the remains of erosive reliefs associated with the action of glacial ice, particularly from striations on slopes, altitude of cirques, erosive traces on gravel and boulders in moraines as well as the state of preservation of the landforms. The presence of some or all of these records in the valley morphology, normally in the lowest glaciated environments, suggested the existence of the Riss, Würm and Late Glacial stages in Sierra Nevada. However, no precise absolute chronology to support this interpretation was produced, only a relative timeline based on morphological and sedimentological differences in the erosive and depositional forms of the glaciated area. From the 1970s onwards there was a tendency to adjust this timeline with pollen record data from the nearby Padul peat bog, which 
includes paleoenvironmental events from 46,440 BP using analysis of taxa in the biostratigraphic core samples from cold, warm and hot-humid periods (Florstchütz et al., 1971; Pons and Reille, 1988; Ortiz et al., 2004).

Sánchez Gómez (1990) suggested possible ancient glaciations in Sierra Nevada, by establishing relationships between the geomorphology and soils of the Lanjarón valley where a sequence of four cold periods and glacial advances were differentiated, based on the degree of evolution of the paleosols existing on moraines and bare summit surfaces without glacial till. Each cold phase was interpreted as being followed by different edaphogenic phases, suggesting that glacial events were interspersed with interglacial periods.

\subsection{Last Glaciation and Late Pleistocene cold crises}

During the Last Glaciation, which can be correlated with the former alpine Würm chronology, the glaciers in Sierra Nevada were restricted to the summit area and adapted to cirque depressions and hollows on the high slopes with occasional transfluence occurring between different cirques. This compartmentalized glaciation was subordinated to the preglacial relief, and left erosive records (U-shaped valleys, polished rock thresholds, arêtes on watersheds, over-deepened basins, etc.) and depositional records (mainly moraines) common throughout the glaciated area, which gave the overall relief in this summit area of Sierra Nevada its alpine morphology (Fig. 3).

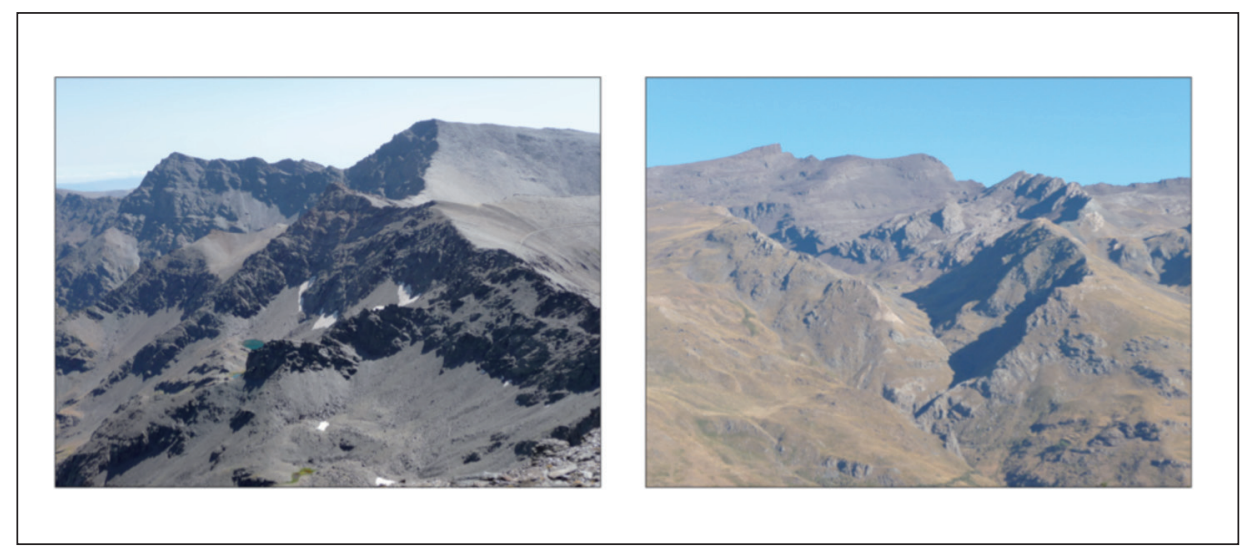

Figure 3. Landscape of the high lands of the massif: Mulhacén (left) and Veleta valley (right).

The valleys sampled for cosmogenic dating purposes were Poqueira (Río Seco and Naute-Mulhacén side valleys), Monachil and Dílar (Table 1). Sampling has also been recently carried out in Lanjarón, San Juan, Hoya de la Mora and Poqueira, Hoya del Capitán sector, downstream from the Poqueira refuge, although chronological data are not available for all these sites. 
Table $1 .{ }^{36} \mathrm{Cl}$ exposure ages, sample type and sample location. Ages are reported assuming 0 erosion rates. Errors correspond to the analytical uncertainty of the $A M S{ }^{36} \mathrm{Cl}$ determination (one standard deviation).

\begin{tabular}{|c|c|c|c|c|c|}
\hline Sample & Sample type & $\begin{array}{c}\text { Zero erosion } \\
\text { age } \\
\text { (ka) }\end{array}$ & $\begin{array}{l}\text { Latitude } \\
\left({ }^{\circ} \mathbf{N}\right)\end{array}$ & $\begin{array}{l}\text { Longitude } \\
\left({ }^{\circ} \mathbf{W}\right)\end{array}$ & $\begin{array}{c}\text { Elevation } \\
\text { (m) }\end{array}$ \\
\hline MULH-M-1 & moraine boulder & $11.6 \pm 0.5$ & $37^{\circ} 01^{\prime} 48.10^{\prime \prime}$ & $3^{\circ} 19^{\prime} 46.90^{\prime \prime}$ & 2461 \\
\hline MULH-M-2 & moraine boulder & $30.0 \pm 1.1$ & $37^{\circ} 01^{\prime} 40.10^{\prime \prime}$ & $3^{\circ} 19^{\prime} 37.60 "$ & 2448 \\
\hline MULH-BR-3 & polished bedrock & $12.0 \pm 0.6$ & $37^{\circ} 02^{\prime} 50.05^{\prime \prime}$ & $3^{\circ} 19^{\prime} 26.47^{\prime \prime}$ & 2912 \\
\hline MULH-BR-4 & polished bedrock & $14.6 \pm 0.8$ & $37^{\circ} 03^{\prime} 01.71^{\prime \prime}$ & $3^{\circ} 19^{\prime} 27.49^{\prime \prime}$ & 3004 \\
\hline MULH-M-5 & moraine boulder & $14.7 \pm 0.7$ & $37^{\circ} 03^{\prime} 10.90^{\prime \prime}$ & $3^{\circ} 19^{\prime} 47.88^{\prime \prime}$ & 3036 \\
\hline MULH-M-6 & moraine boulder & $8.7 \pm 0.4$ & $37^{\circ} 03^{\prime} 10.27^{\prime \prime}$ & $3^{\circ} 19^{\prime} 50.48^{\prime \prime}$ & 3090 \\
\hline SECO-M-1 & moraine boulder & $14.2 \pm 0.8$ & $37^{\circ} 01^{\prime} 43.40^{\prime \prime}$ & $3^{\circ} 20^{\prime} 08.50^{\prime \prime}$ & 2423 \\
\hline SECO-M-2 & moraine boulder & $13.4 \pm 0.7$ & $37^{\circ} 01^{\prime} 42.40^{\prime \prime}$ & $3^{\circ} 20^{\prime} 11.10^{\prime \prime}$ & 2437 \\
\hline SECO-M-3 & moraine boulder & $19.0 \pm 1.0$ & $37^{\circ} 01^{\prime} 40.40^{\prime \prime}$ & $3^{\circ} 20^{\prime} 12.40^{\prime \prime}$ & 2446 \\
\hline SECO-BR-4 & polished bedrock & $12.7 \pm 0.6$ & $37^{\circ} 02^{\prime} 58.03{ }^{\prime \prime}$ & $3^{\circ} 20^{\prime} 41.63 \prime$ & 2984 \\
\hline SECO-RG-5 & rock glacier boulder & $9.6 \pm 0.4$ & $37^{\circ} 02^{\prime} 46.75^{\prime \prime}$ & $3^{\circ} 20^{\prime} 37.84 \prime$ & 2895 \\
\hline DILAR-RG-1 & rock glacier boulder & $12.0 \pm 0.5$ & $37^{\circ} 03^{\prime} 12.57^{\prime \prime}$ & $3^{\circ} 24^{\prime} 14.25^{\prime \prime}$ & 2583 \\
\hline DILAR-RG-2 & rock glacier boulder & $9.1 \pm 0.7$ & $37^{\circ} 02^{\prime} 49.57^{\prime \prime}$ & $3^{\circ} 23^{\prime} 55.41^{\prime \prime}$ & 2784 \\
\hline DILAR-RG-3 & rock glacier boulder & $7.5 \pm 0.4$ & $37^{\circ} 02^{\prime} 40.99^{\prime \prime}$ & $3^{\circ} 24^{\prime} 13.17^{\prime \prime}$ & 2870 \\
\hline DILAR-BR-4 & polished bedrock & $14.3 \pm 0.5$ & $37^{\circ} 03 ’ 32.66^{\prime \prime}$ & $3^{\circ} 23^{\prime} 02.38^{\prime \prime}$ & 2828 \\
\hline DILAR-BR-5 & polished bedrock & $15.4 \pm 2.2$ & $37^{\circ} 03^{\prime} 27.70^{\prime \prime}$ & $3^{\circ} 22^{\prime} 55.37^{\prime \prime}$ & 2873 \\
\hline DILAR-VP-6 & bedrock & $32.1 \quad 0.8$ & $37^{\circ} 03{ }^{\prime} 34.99^{\prime \prime}$ & $3^{\circ} 22^{\prime} 10.77^{\prime \prime}$ & 3211 \\
\hline MONA-M-1 & moraine boulder & 13.9 & $37^{\circ} 05^{\prime} 40.17^{\prime \prime}$ & $3^{\circ} 24^{\prime} 19.49^{\prime \prime}$ & 2006 \\
\hline MONA-M-2 & moraine boulder & $19.6 \quad 0.8$ & $37^{\circ} 05^{\prime} 42.70^{\prime \prime}$ & $3^{\circ} 24^{\prime} 22.64^{\prime \prime}$ & 1975 \\
\hline
\end{tabular}

The oldest dating of moraine remains in valleys on the south face of the Sierra show the maximum expansion of the glaciers during the Last Glaciation at approx. 30-32 ka (the upper Poqueira Gorge, Naute-Mulhacén lateral Valley, 2448 m) (Fig. 4). For the rock substratum, the oldest cosmogenic dating coincides on the western face of El Veleta hörn, (3211 m), obtaining an age of 32 ka (Gómez-Ortiz et al., 2012). 


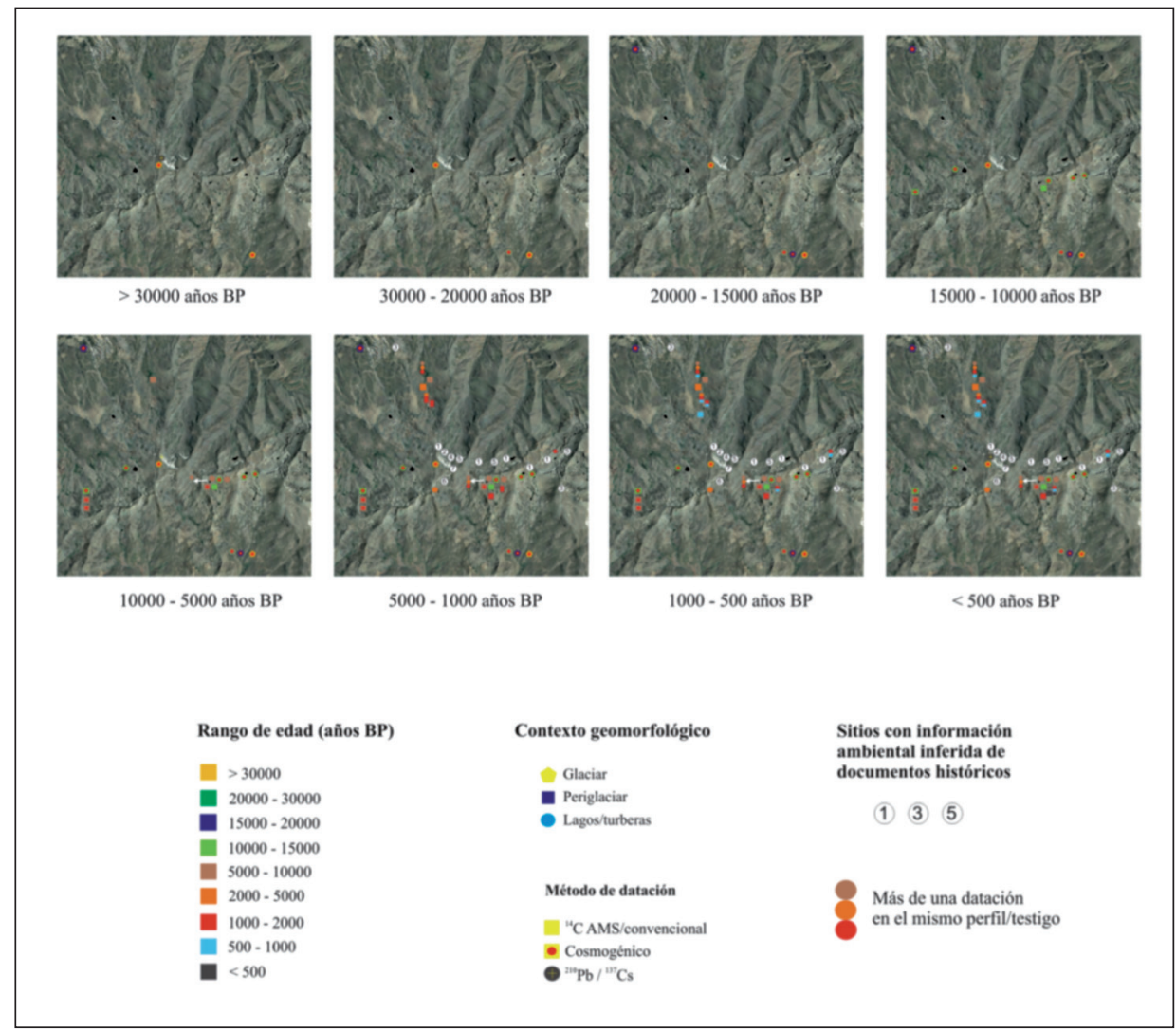

Figure 4. Datings according to the age range, geomorphological environment and dating method.

In all the valleys examined with chronological results there are no ages available between 30 and $20 \mathrm{ka}$, which prevents any evaluation of the glacial masses on the massif during this period. But from 20-19 ka several records in the glaciated area distributed across valleys and cirques suggested a phase of second glacial re-advance.

The dates obtained from 20-19 ka are repeated in different valleys (Monachil, westfacing and Río Seco, south-facing). In the Monachil valley a left-front lateral moraine segment at altitude $1975 \mathrm{~m}$ near the Pradollano winter resort obtained $19.6 \mathrm{ka}$ (Fig. 5). And in Río Seco, in the lowest reach near the confluence with the Naute River, a stepped sequence of lateral moraine segments at different altitudes yielded ages of 19.0; 13.4 and $14.2 \mathrm{ka}$. Immediately afterwards, the glacier installed in each valley tended to retreat towards the cirque walls leaving erosive records on the bedrock surfaces. This occurred in the interior of the Naute-Mulhacén valley (threshold at $3036 \mathrm{~m}, 14.6 \mathrm{ka}$ ), at the head of the Dílar cirque, in the rocky steps of Las Yeguas (15.4 and 14.3 ka) and in Río Seco (12.7 ka). 


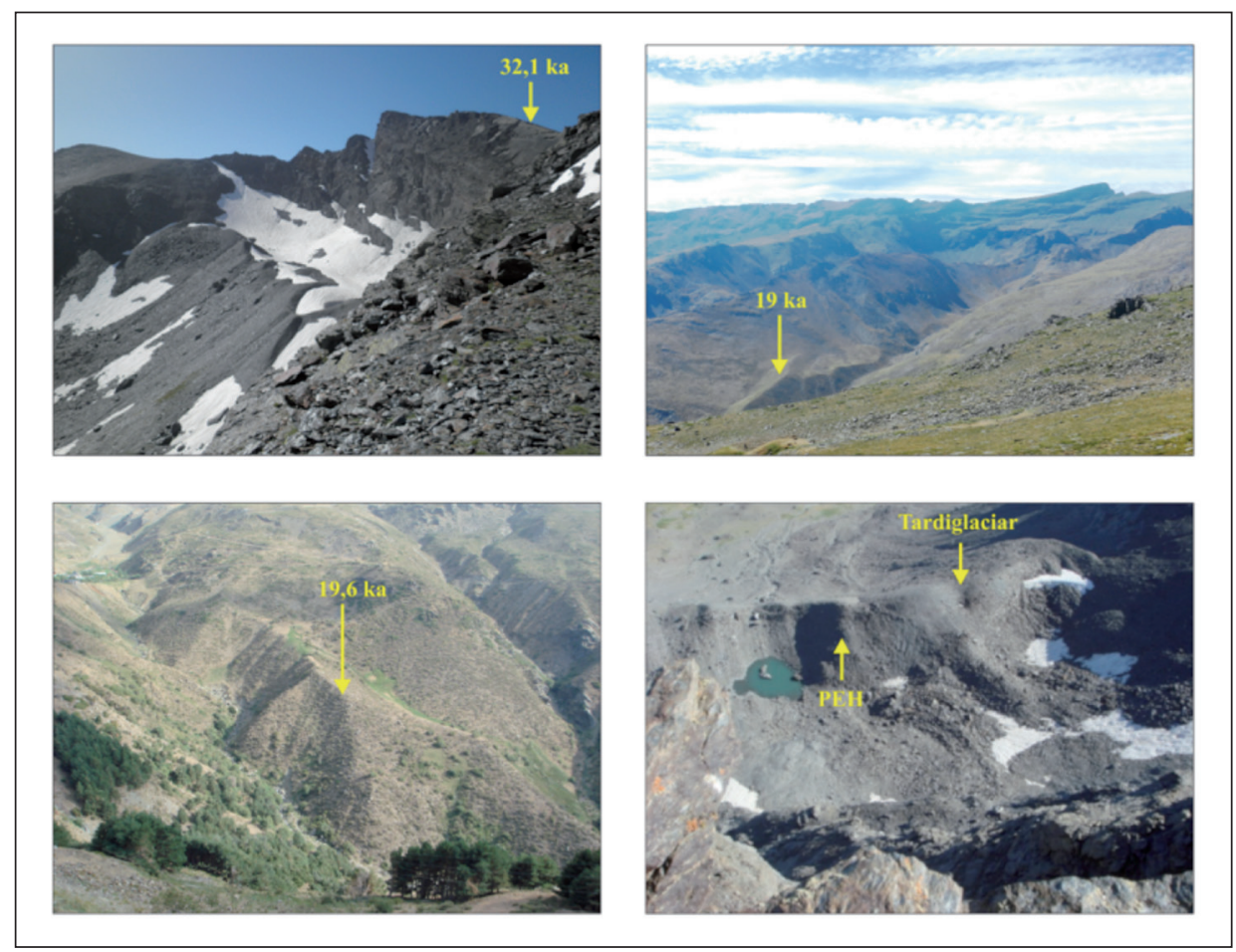

Figure 5. Location and results of the datings in some areas of the massif: Veleta peak (above, left), lateral moraine in Rio Seco valley (above, right lateral moraine in Monachil valley (below, left) and moraine formed during the Late Glacial and LIA in the Veleta cirque (below, right).

The final phase of the Last Glaciation does not seem to show any notable glacial repercussions on the peaks of the Sierra. It must have been most intense on the north face inside the cirques, e.g. in Hoya del Mulhacén and Corral del Veleta, and to a lesser extent on the south face in La Caldera cirque, with all glaciers enclosed by terminal moraine ridges. No absolute dating exists for these morphologies, making it difficult to establish the chronology of their formation. Relevant information is only available for La Caldera, with $14.7 \mathrm{ka}$, which may be considered coherent if we take into account that for the adjacent Rio Seco cirque a soil formation has been detected at $12.9 \mathrm{ka}$ BP (Oliva, 2009; Oliva et al., 2014), suggesting that this glacier cirque remained ice-free during that period.

The deglaciation of the massif was completed immediately afterwards as confirmed by cosmogenic dating carried out on stable blocks located in different generations of rock glaciers. This occurs at the head of the Dílar, in the Cascajares del Cartujo, where the succession of arcs forming the relief offers a range of ages, with $12.1 \mathrm{ka}$ in the oldest generation at altitude $2583 \mathrm{~m} ; 9.1 \mathrm{ka}$ in the intermediate and $7.5 \mathrm{ka}$ in the most recent at $2870 \mathrm{~m}$. These morphologies are also found at similar altitudes on the south face with ages of 9.6 ka obtained for Río Seco and 8.7 ka for Mulhacén valleys. 


\subsection{The Holocene and the Little Ice Age}

At the start of the present interglacial, the increase in temperature conditioned the existing geomorphological dynamics in Sierra Nevada. The Holocene is characterized by the predominance of periglacial processes in the massif, with only ephemeral appearances of glaciers in the highest northern cirques (Oliva et al., 2014).The stabilization of the rock glaciers around $7 \mathrm{ka} \mathrm{BP}$ occurred in parallel to the formation of histosols with very high organic material content on valley bottoms on both slopes. These conditions predominated during the Middle Holocene, implying prevalent geomorphic stability, extension of scattered vegetation on slopes and formation of grasslands (known here as borreguiles) in areas with flat topography and abundant supply of meltwater. During the last 4 millennia the aridity in Sierra Nevada has intensified as shown by lacustrine sediments and distribution of solifluction records in the massif (Oliva et al., 2011). However, the sedimentary sequences show significant changes in the prevailing environmental conditions over $2500 \mathrm{~m}$ in Sierra Nevada during these millennia. In this context, a series of cold wet periods is detected, with enhanced periglacial activity extending to lower altitudes. At the same time, warmer periods promoted intense edaphogenesis, resulting in greater geomorphic stability and increased vegetation colonization (Oliva, 2009b).

Based on the analysis of the lacustrine sediments of the Laguna de la Mosca, Oliva and Gómez-Ortiz (2012) have detected the existence of a glacier at three different times over the last three millennia in the Hoya del Mulhacén, between 2800-2700, 1400-1200 and 510-240 yrs cal BP. During these short time periods the climatic conditions must have been colder and wetter than present-day. The most recent and intense of these periods corresponds to the LIA in Sierra Nevada, well documented in historical texts, above all by references to perennial snow patches (cirque glaciers) located below the highest summits of the northern slopes, between the Mulhacén and Veleta peaks (Madoz, 1849).

\section{Discussion}

The glaciers in Sierra Nevada shaped the summits of this massif above 2500-2600 m. The areas affected by glacial processes were conditioned by the preglacial relief, namely by the valley network and its tributaries and their exposition to the Atlantic or Mediterranean influences. The Last Glaciation generated cirque and alpine valley glaciers and also hanging glaciers on valley sides, disconnected from the main glacial valley. The summit surfaces did not host ice fields, as shown by the lack of traces of glacial abrasion as well as the sediments overlaying older edaphic horizons than those found in the valley moraines (Sánchez-Gómez, 1990). These high plateaus must have acted as cryoplanation surfaces during the Last Glaciation.

The abundant depositional and erosive glacial, periglacial, lacustrine and peat records distributed in the glaciated domain of the valleys studied makes possible to establish a detailed timeline regarding the environmental evolution of Sierra Nevada since the Last Glaciation. 
The maximum extent of the glacial ice in Sierra Nevada (32-30 ka at the Poqueira and Naute/Mulhacén valleys) precedes the global Last Glacial Maximum, probably in response to higher precipitation indices in the massif than those recorded during the global temperature minimum (Gómez-Ortiz et al., 2012). However, it is uncertain what happened with the glacier systems between 30 and $20 \mathrm{ka}$. The permanence of cold temperatures during the final millennia of the last North Atlantic glaciation -also detected in isotopic records of the Mediterranean Sea (Hayes et al., 2005; Mikolajewicz, 2011) - suggests that the glaciers may not have disappeared in this phase, although they did experience minor advances and retreats (Oliva et al., 2014). In fact, these must have been of less spatial significance than the advance recorded in 19-20 ka BP, close to the maximum extent reached around ten millennia earlier (Gómez-Ortiz et al., 2012). This second maximum advance phase is detected in other Iberian massifs with Atlantic climatic influence (Moreno et al., 2010; Ruiz-Fernández, 2013; Serrano et al., 2013). It corresponds to the maximum expansion of glacier ice in central and northeastern Iberian massifs (Palacios et al., 2011, 2012, 2015).

The main deglaciation in Sierra Nevada started around 19-18 ka, and occurred synchronically in most of the glaciated mountains in the Northern Hemisphere during the Last Deglaciation (Clark et al., 2009). In Sierra Nevada, the ice retreated rapidly towards the headwalls. This was the case of the Río Seco cirque near the lake, where polished rock at an altitude of $2984 \mathrm{~m}$ yielded an age of $12.7 \mathrm{ka}$, and $12.9 \mathrm{ka} \mathrm{BP}$ for the deepest edaphic layer in a solifluction lobe of the same cirque (Oliva, 2009). The same occurred in the Poqueira basin, downstream from the Caldera cirque, where the polished rock thresholds of the river bed at elevations around $3000 \mathrm{~m}$ resulted in ages of 14.6 and $12 \mathrm{ka}$. This also occurred in the Dílar valley, where the base of the cirque at an altitude of $2850 \mathrm{~m}$ became ice-free at $15.4 \mathrm{ka}$ and $14.3 \mathrm{ka}$, according to the age of the polished rock near Las Yeguas Lake (15.4 ka and 14.3 ka). (Gómez-Ortiz et al., 2012). Terrestrial (Ortiz et al., 2004) and marine (Cacho et al., 2000; Fletcher et al., 2010) records of the Sierra Nevada regional area indicate a notable temperature increase during this period, which would have led to a rapid reduction of the glaciated area and the implementation of periglacial processes in the summit areas of the massif.

The glacial imprint left by the Late Glacial cold phase in Sierra Nevada is limited to the development of small moraine ridges in the highest northern cirques and to the formation of rock glaciers (Gómez-Ortiz et al., 2012). In contrast to what occurred in the Pyrenees or in the Alps where the Younger Dryas resulted in significant glacial advance (Pallàs et al., 2006; Ivy-Ochs et al., 2008, 2009), in Sierra Nevada the glacial ice was confined, particularly at the head of the steep northern valleys, conditioned by the morphotopographic restrictions of the relief and the prevailing cold and dry conditions (Oliva et al., 2014). These conditions led to a general reactivation of periglacial processes, very active in the interior of the cirques (Palade et al., 2011; Gómez-Ortiz et al., 2013). The most significant morphologies created during this phase correspond to the rock glaciers located on the cirque walls. In the Dílar cirque, where these are most well developed, they were active between 12 and $7.5 \mathrm{ka}$. 
The onset of the Holocene conditioned an increasing altitude of the periglacial activity in Sierra Nevada, now located in the highest summit belt, while vegetation began to colonize valley sides and slopes above $2500 \mathrm{~m}$, forming the current grasslands (Oliva, 2009). However, during the Early Holocene some rock glaciers at altitudes of $2800 \mathrm{~m}$ on the north face, e.g. in the Dílar cirque, maintained a certain dynamism until $7.5 \mathrm{ka}$, when they stabilized (Gómez-Ortiz et al., 2012). Since then, the prevalence of less rigorous climatic conditions has allowed the periglacial domain to control the biophysical dynamics in the massif (Oliva, 2009). Nevertheless, sedimentological and geochronological analysis of the solifluction landforms revealed alternating climatic periods from the Mid-Holocene until the present, characterized by warmer/colder phases with oscillating moisture conditions. The warmer phases resulted in a relative extension of the scattered vegetation cover and intensification of the edaphic processes; the colder phases meant a reactivation of the periglacial slope processes (e.g. solifluction), with greater mineral remotion and mechanical activity on the slopes (Oliva et al., 2011). This occurred parallel to intensifying aridity in Sierra Nevada from $4.2 \mathrm{ka}$ cal BP (Oliva et al., 2011) and to the increasing desertification in northern Africa during the Middle Holocene (Gasse, 2000) together with increased variability of the Earth's climate (Mayewski et al., 2004). The last of these cold phases occurred in historical times and corresponds to the LIA.

During the LIA (14 ${ }^{\text {th }}-19^{\text {th }}$ cent.) Sierra Nevada hosted the southernmost glaciers in Europe. These were small glaciers enclosed in the highest basins at the valley cirques, especially in the Picón de Jeres and Picacho del Veleta areas. The existence of these glaciers is well documented in palynological and lake sediment records (Esteban, 1995; Oliva, 2009a), as well as in contemporary writings (Boissier, 1845; Madoz, 1849). The Corral del Veleta glacier was the most important and longest lasting of all these historical glaciers, with its remnants persisting until the mid-20 ${ }^{\text {th }}$ century (García Sainz, 1947). Precise information on its existence and evolution is available since 1754 (Ponz, 1754).

There is currently no visible trace of this historical glaciation but frozen remains of the glacier hosted inside the Corral de Veleta at that time are still preserved in the ancient Quaternary cirque of the Guarnón glacier, where relict glacier ice and permafrost persist under a rock glacier at an altitude of $3100 \mathrm{~m}$ (Gómez-Ortiz et al., 2013). Physical monitoring of these frozen bodies has been carried out since the year 2000, confirming an ongoing process of deterioration resulting in reduction and compartmentalization, both in surface area and thickness. This deterioration is basically related to the lack of snow on the ground during the summer, which allows the external thermal wave to penetrate the active layer reaching the glacial ice and permafrost table (Gómez-Ortiz et al., 2014).

\section{Conclusions}

Sierra Nevada forms a high semi-arid massif located in the extreme SW of the Mediterranean alpine belt, which has been affected by ancient glaciations although absolute dating of their traces has not yet been obtained. The available environmental 
and chronological information does however enable the reconstruction of the precise environmental sequence that took place from the maximum ice extent during the Last Glaciation. This is explained by the abundant natural records analysed (erosive and depositional landforms in summit areas) facilitating information and timing of glaciological and geomorphological events in this glacial period and during the Holocene. The geomorphological significance of the LIA on the summits of this mountain in historical times has also been determined in this case from complementary written documents of the time and also again from natural records.

The maximum advance of the alpine glaciers channelled through the steep valleys of Sierra Nevada occurred around 30-32 ka, with a later re-advance at 19-20 ka. Based on the erosive records on the valley bottoms, the glacial retreat towards the headwall must have been rapid at around 14-15 ka. From this date onwards the glacier ice was already retreating to the area next to the cirque walls with a favourable orientation. This can be seen in Río Seco where the glacial erosion of the bedrock has been dated at $12.7 \mathrm{ka}$, and paleosol at $12.9 \mathrm{ka} \mathrm{BP}$. This environmental change must have led to prevailing periglacial processes on the summit areas of Sierra Nevada, which extended over the areas that had recently become ice-free.

The Late Glacial in Sierra Nevada promoted an ephemeral presence of small glaciers in the highest cirques, and the widespread presence of rock glaciers favoured by the prevailing cold and dry climate conditions. The orientation of the mountain slopes and the higher amounts of precipitation in the area of the massif with greater climatic influence of the Atlantic Ocean explain this fact. This can be seen in the north face of the Sierra, where rock glaciers developed inside the cirque walls; in the case of El Dílar site, rock glaciers must have remained active until 12-7.5 ka, although with decreasing intensity.

Periglacial processes gradually retreated to higher levels during the Holocene, with decreasing intensity, especially in the lower areas of the Sierra, where the vegetation started to stabilize. Nevertheless, during the Holocene there is evidence of alternating colder/warmer periods with fluctuating humidity conditions. Above $2500 \mathrm{~m}$ this is reflected in greater geomorphic activity linked to periglacial dynamics with less vegetation presence during cold phases and an expansion of the vegetal colonization during warm periods with the formation of highly organic soils on the valley bottoms. All this occurred in spite of the trend towards greater aridity on a millennium scale in the south of the Iberian Peninsula.

The coldest and wettest Holocene phases facilitated the secular reappearance of small cirque glaciers in the north facing cirques at the highest altitudes. This is confirmed by sedimentological data from Laguna de la Mosca in the Hoya del Mulhacén, where a small glacier was active between 2800-2700, 1400-1200 years. ago and during the LIA. Cirque glaciers were also generated precisely in these enclosed areas during the LIA as a result of the combined action of ice, snow, cold and wind. The most representative of these glaciers, in the Corral del Veleta, was described repeatedly in the contemporary literature. From the information provided by these documents and by the lacustrine sediments from the La Mosca lake, we can deduce that the LIA was the coldest and 
wettest phase of the last three millennia in Sierra Nevada, with annual mean temperatures at least $0.93^{\circ} \mathrm{C}$ lower than those presently recorded.

Since the late 19th century the temperature increase conditioned the gradual shrinkage of the glacier that existed in the Corral del Veleta. Its remains were visible until the mid-20th century, thus culminating the complete deglaciation of Sierra Nevada.

\section{Acknowledgements}

This study was performed with the support of the projects CGL2012-35858 and CSO2012-30681 (Ministerio de Economía y Competitividad-Plan Nacional I+D+i) and 016/2007 (Ministerio de Medio Ambiente, OAPN) and the Research Group "Paisatge i paleoambients a la muntanya mediterrània" (2013SGR373). We also particularly thank to the Sierra Nevada National Park for its support in the field.

\section{References}

Blanco-Pastor, J.L., Fernández-Mazuecos, M., Vargas, P. 2013. Past and future demographic dynamics of alpine species: limited genetic consequences despite dramatic range contraction in a plant from the Spanish Sierra Nevada. Molecular Ecology 22, 4177-4195.

Boissier, C.E. 1845. Voyage botanique dans le midi de l'Espagne pendant l'année 1837. Granada: Fundación Caja de Granada and Universidad de Málaga, Granada. Reprint 1995.

Cacho, I., Grimalt, J., Sierro, F., Flores, J., Shackleton, N., Canals, M. 2000. Evidence for enhanced Mediterranean thermohaline circulation during rapid climatic coolings. Earth and Planetary Science Letters 183, 417-429.

Clark, P.U., Dyke, A.S., Shakun, J.D., Carlson, A.E., Clark, J., Wohlfarth, B., Mitrovica, J.X., Hostetler, S.W., McCabe, A.M. 2009. The Last Glacial Maximum. Science 325, 710-714.

Delmas, M., Calvet, M., Gunnell, Y., Braucher, R., Bourlès, D. 2011. Palaeogeography and ${ }^{10} \mathrm{Be}$ exposure-age chronology of Middle and Late Pleistocene glacier systems in the northern Pyrenees: Implications for reconstructing regional palaeoclimates. Palaeogeography, Palaeoclimatology, Palaeoecology 305, 109-122.

Delmas, M., Gunnell, Y., Braucher, R., Calvet, M., Bourlès, D. 2008. Exposure age chronology of the last glaciation in the eastern Pyrenees. Quaternary Research 69, 231-241.

Díaz de Federico, A., Puga, E., Burgos, J., Gallegos, J.A., Sanz de Galdeano, C. 1980. Mapa Geológico de España, Hoja 1027, Güejar-Sierra. Instituto Geológico y Minero de España, Madrid.

Domínguez-Villar, D., Carrasco, R.M., Pedraza, J., Cheng, H., Edwards, R.L., Willenbring, J.K. 2013. Early maximum extent of paleoglaciers from Mediterranean mountains during the last glaciation. Scientific Reports, 3, 2034, doi: 10.1038/srep02034.

Dresch, J. 1937. De la Sierra Nevada au Grand Atlas, formes glaciaires et formes de nivation. Mélanges de geographie et d'orientalisme offerts a E.F. Gautier, Tours, pp. 194-212.

Esteban, A. 1995. Evolución del paisaje durante los últimos 10.000 años en las montañas del Mediterráneo Occidental: ejemplos del Pirineo Oriental y Sierra Nevada. Ph.D. Thesis, University of Barcelona, Spain.

Fletcher, W.J., Sánchez-Goñi, M.F., Peyron, O., Dormoy, I. 2010. Abrupt climate changes of the last deglaciation detected in a Western Mediterranean forest record. Climate of the Past, 6 , 245-264. 
Florschütz, F., Menéndez Amor, J., Wijmstra, T.A. 1971. Palynology of a thick Quaternary succession in southern Spain. Paleogeography, Paleoclimatology, Paleoecology 10, 233264.

García-Ruiz, J.M., Moreno, A., González-Sampériz, P., Valero-Garcés, B., Martí-Bono, C. 2010. La cronología del último ciclo glaciar en las montañas del sur de Europa. Una revisión. Cuaternario y Geomorfología 24 (1-2), 35-46.

García Sainz, L. 1943. El glaciarismo cuaternario en Sierra Nevada. Estudios Geográficos 4, 233-254.

García Sainz, L. 1947. El clima de la España cuaternaria y los factores de su formación. Secretariado de Publicaciones de la Universidad de Valencia, Valencia.

Gasse, F. 2000. Hydrological changes in the African tropics since the Last Glacial Maximum. Quaternary Science Reviews 19, 189-211.

Gómez-Ortiz, A. (coord.) 2002. Mapa geomorfológico de Sierra Nevada. Consejería de Medio Ambiente de la Junta de Andalucía, Granada.

Gómez-Ortiz, A. 1987. Morfología glaciar en la vertiente meridional de Sierra Nevada (área Veleta-Mulhacén). Estudios Geográficos 193, 527-558.

Gómez-Ortiz, A., Oliva, M., Salvador-Franch, F., Salvà-Catarineu, M., Palacios, D., Sanjosé, J.J., Tanarro, L., Galindo-Zaldívar, J., Sanz de Galdeano, C. 2014. Degradation of buried ice and permafrost in the Veleta cirque (Sierra Nevada, Spain) from 2006-2013. Solid Earth 5, 979-993.

Gómez-Ortiz, A., Palacios, D., Palade, B., Vázquez-Selem, L., Salvador-Franch, F., Tanarro, L., Oliva, M. 2013. La evolución glaciar de Sierra Nevada y la formación de glaciares rocosos. Boletín de la Asociación de Geógrafos Españoles 61, 139-162.

Gómez-Ortiz, A., Palacios, D., Palade, B., Vázquez-Selem, L., Salvador-Franch, F. 2012. The deglaciation of the Sierra Nevada (Southern Spain). Geomorphology, 159-160, 93-105.

Gómez-Ortiz, A., Palacios, D., Schulte, L., Salvador-Franch, F., Plana, J.A. 2009. Evidences from historical documents of landscape evolution after Little Ice Age of a Mediterranean high mountain area, Sierra Nevada, Spain (eighteenth to twentieth centuries). Geografiska Annaler, Series A, Physical Geography 91, 279-289.

Gómez-Ortiz, A., Plana-Castellví, J.A. 2006. La Pequeña Edad del Hielo en Sierra Nevada a partir de los escritos de la época (siglos XVIII y XIX) y relaciones con el progreso de la geografía física y geomorfología española. Boletín de la Asociación de Geógrafos Españoles 42, 7198.

Gómez-Ortiz, A., Pérez-González, A. (eds.) 2001. Evolución reciente de la Geomorfología española 1980-2000. Aportación española a la V Conferencia Internacional de Geomorfología (Tokyo, 2001). Sociedad Española de Geomorfología and Servei de Gestió i Evolució del Paisatge of the University of Barcelona, Barcelona.

Gómez-Ortiz, A., Salvador-Franch, F. 1992. Aportaciones significativas al conocimiento del glaciarismo y periglaciarismo de Sierra Nevada. Notes de Geografia Física 20-21, 89-101.

González Trueba, JJ, Martín Moreno, R, Martínez de Pisón, E., Serrano, E. 2008. Little Ice Age glaciation and current glaciers in the Iberian Peninsula. The Holocene 18 (4), 551-568.

Hayes, A., Kuceram M., Kallel, N., Sbaffi, L., Rohling, E.J. 2005. Glacial Mediterranean sea surface temperatures based on planktonic foraminiferal assemblages. Quaternary Science Reviews 24, 999-1016.

Hempel, L. 1960. Límites altitudinales geomorfológicos en Sierra Nevada. Estudios Geográficos 78, 81-93.

Ivy-Ochs, S., Kerschner, H., Maisch, M., Christl, M., Kubik, P.W. 2009. Latest Pleistocene and Holocene glacier variations in the European Alps. Quaternary Science Reviews 28, 21372149 . 
Ivy-Ochs, S., Kerschner, H., Reuther, A., Preusser, F., Heine, K., Masich, M., Kubik, P.W., Schlüchter, C. 2008. Chronology of the last glacial cycle in the European Alps. Journal of Quaternary Science 23, 559-573.

Lhenaff, R. 1977. Recherches géomorphologiques sur les Cordillères Bétiques centrooccidentales (Espagne). Ph.D. Thesis, University of Lille, France.

Macpherson, J. 1875. De la existencia de fenómenos glaciares en el sur de Andalucía durante la época cuaternaria. Acta de la Sociedad Española de Historia Natural IV, 56-61.

Madoz, P. 1849. Diccionario Geográfico-Estadístico-Histórico de España y sus posesiones de ultramar. Madrid, Vol. 14, pp. 383-386.

Mayewski, P.A., Rohling, E.E., Stager, J.C., Karlen, W., Maasch, K.A., Meeker, L.D., Meyerson, E.A., Gasse, F., Van Kreveld, S., Holmgren, K., Lee-Thorp, J., Rosqvist, G., Rack, F., Staubwasser, M., Schneider R.R., Steig, E.J. (2004). Holocene climate variability. Quaternary Research 62, 243-255.

Messerli, B. 1965. Beiträge zur Geomorphologie der Sierra Nevada (Andalusien). Juris Verlag. Zürich.

Mikolajewicz, U. 2011. Modeling Mediterranean Ocean climate of the Last Glacial Maximum. Climate of the Past 7, 161-180.

Molero Mesa, J., Pérez Raya, F. 1987. La flora de Sierra Nevada. Granada, University of Granada.

Moreno, A., Valero-Garcés, B.L., Jiménez-Sánchez, M., Domínguez-Cuesta, M.J., Mata, M.P., Navas, A., González-Sampériz, P., Stoll, H., Farias, P., Morellón, M., Corella, J.P., Rico, M. 2010. The last deglaciation in the Picos de Europa National Park (Cantabrian Mountains, Northern Spain). Journal of Quaternary Science 25 (7), 1076-1091.

Obermaier, H. 1916. Los glaciares cuaternarios de Sierra Nevada. Trabajos del Museo Nacional de Ciencias Naturales (Geología) 17, 1-68.

Oliva, M. 2009. Reconstrucció paleoambiental holocena de Sierra Nevada a partir de registres sedimentaris. Tesis doctoral. Universidad de Barcelona.

Oliva, M., Gómez-Ortiz, A., Palacios, D., Salvador-Franch, F., Salvà-Catarineu, M. 2014. Environmental evolution in Sierra Nevada (South Spain) since the Last Glaciation based on multi-proxy records. Quaternary International 353, 195-209.

Oliva, M., Gómez-Ortiz, A. 2012. Late Holocene environmental dynamics and climate variability in a Mediterranean high mountain environment (Sierra Nevada, Spain) inferred from lake sediments and historical sources. The Holocene 22 (8), 915-927.

Oliva, M., Schulte, L., Gómez-Ortiz, A. 2011. The role of aridification in constraining the elevation range of Holocene solifluction processes and associated landforms in the periglacial belt of the Sierra Nevada (Southern Spain). Earth Surface Processes and Landforms 36, 1279-1291.

Oliva, M., Schulte, L., Gómez-Ortiz, A., 2009. Morphometry and Late Holocene activity of solifluction landforms in the Sierra Nevada (Southern Spain). Permafrost and Periglacial Processes 20 (4), 369-382.

Ortiz, A., Torres, T., Delgado, A., Julià, R., Lucini, M., Llamas, F.J. 2004. The palaeoenvironmental and palaeohydrological evolution of Padul peat bog (Granada, Spain) over one million years from elemental, isotopic and molecular organic geochemical proxies. Organic geochemistry $35,1243-1260$.

Palacios, D., Gómez-Ortiz, A., de Andrés, N., Vázquez-Selem, L., Salvador-Franch, F., Oliva, M. 2014. Maximum extent of Late Pleistocene glaciers and Last Deglaciation of La Cerdanya mountains, Southeastern Pyrenees. Geomorphology (in press).

Palacios, D., Gómez-Ortiz, A., de Andrés, N., Vázquez-Selem, L., Salvador-Franch, F., Oliva, M. 2015. Maximum extent of Late Pleistocene glaciers and Last Deglaciation of La Cerdanya mountains, Southeastern Pyrenees. Geomorphology 231, 116-129. 
Palacios, D., de Andrés, N., de Marcos, J., Vázquez-Selem, L. 2012. Glacial landforms and their paleoclimatic significance in Sierra de Guadarrama, Central Iberian Península. Geomorphology 139-140, 67-78.

Palacios, D., de Marcos, J., Vázquez-Selem, L. 2011. Last Glacial Maximum and deglaciation of Sierra de Gredos, central Iberian Peninsula. Quaternary International 233, 16-26.

Palade, B., Gómez-Ortiz, A., Palacios, D. 2011. Glaciares rocosos de Sierra Nevada y su significado paleoclimático: una primera aproximación. Cuadernos de Investigación Geográfica 37, 95118 .

Pallàs, R., Rodés, A., Braucher, R., Carcailler, J., Ortuño, M., Bordonau, J., Bourlès, D., Vilaplana, J.M., Masana, E., Santanach, P. 2006. Late Pleistocene and Holocene glaciation in the Pyrenees: a critical review and new evidence from ${ }^{10} \mathrm{Be}$ exposure ages, south-central Pyrenees. Quaternary Science Reviews 25, 2937-2963.

Paschinger, H. 1957. Las formas glaciares de Sierra Nevada. Memorias y Comunicaciones del Instituto Geológico Provincial de Barcelona, Barcelona, pp. 81-94.

Pons, A., Reille, M. 1988. The Holocene and upper Pleistocene pollen record from Padul (Granada, Spain): a new study. Palaeogeography, Palaeoclimatology, Palaeoecology 66, 243-263.

Ponz, A. 1754. Relación del viaje que hizo desde Granada a Sierra Nevada D. Antonio Ponz a influxo del Excmo. Sr. Marqués de la Ensenada. Mensagero Económico y Erudito de Granada, Vol. 25-30, Granada.

Ruiz-Fernández, J. 2013. Las formas de modelado glaciar, periglaciar y fluviotorrencial del Macizo Occidental de los Picos de Europa (Cordillera Cantábrica). Unpublished PhD Thesis, Universidad de Oviedo.

Salvador-Franch, F., Gómez-Ortiz, A., Salvà-Catarineu, M., Palacios, D. 2011. Caracterización térmica de la capa activa de un glaciar rocoso en medio periglaciar de alta montaña Mediterránea. Cuadernos de Investigación Geográfica 37 (2), 25-48.

Sánchez-Gómez, S. 1990. Aplicación del estudio de suelos a la dinámica de la cuenca del río Lanjarón. Relación suelos-geomorfología. Unpublished PhD Thesis, University of Granada, Spain.

Sanz de Galdeano, C., López-Garrido, A.C. 1999. Nature and impact of the neotectonic deformation in the western Sierra Nevada (Spain). Geomorphology 30 (3), 259-272.

Schimper, P. 1849. Voyage géologique et botanique au Sud de 1'Espagne. Journal de l'Institut, Jounal Universel des Sciences 806, 189-192. Paris.

Serrano, E., González-Trueba, J.J., Pellitero, R., González-García, M., Gómez, M. 2013. Quaternary glacial evolution in the Cantabrian Mountains (Northern Spain). Geomorphology 196, 65-82.

Solé Sabarís, L. 1951. Los Pirineos. Editorial Alberto Martín. Barcelona. 